\title{
15
}

\section{Real Life and the Classroom}

\author{
Shauna Van Praagh \\ McGill University
}

The choices teachers make about both form and content in designing their courses shape students' perceptions of the connection between 'real life' and the 'classroom.' The choice to begin a first-year law course with stories told by residential school survivors provides an example of how to bring 'real life' into the classroom in a way which develops both critical understanding of ideas and capacity for identity-based roles and responsibilities. Classroom and 'real life' merge through issues and pedagogical approaches that combine deep reflection with active participation.

\section{Introduction: Pedagogical Choices}

W hether with respect to substance or content, instructors in the realm of higher education make significant choices relevant to the links between life and learning. When, for example, they use contemporary examples to explore concepts and constructs, the content of what is taught challenges boundaries between 'real life' and the 'classroom.' Such substantive choices in selecting focal points for study and discussion are mirrored by pedagogical choices. Indeed, choices as to form and approach in teaching are as important as their substantive counterparts. They are important not only to dynamic and meaningful education in a university classroom, but to the roles and responsibilities taken on by students after they graduate.

The example I explore in this short paper is drawn from university legal education, and, more specifically, from a foundational course in law that examines modes of governance and interpersonal responsibility. It serves to illustrate that the project of making learning in the classroom relevant to 'real life' is not confined to the content of the material and discussions; it is equally, or even more significantly, within the realm of pedagogical approach and responsibility. As an example of substantive and pedagogical choices that challenge the boundaries between real life and the law classroom, the incorporation of Canada's residential school legacy into a basic course discussed below - is necessarily grounded in a particular context. And yet, its lessons are relevant across disciplinary boundaries. They are meant to inspire and sustain efforts to connect classroom creativity and constructive experiences to relevant and topical course content.

\section{Ideas and Identity; Substance and Skills}

As university teachers, how do we understand and respond to our students' questioning of the relevance to 'real life,' and to the ways in which they live and act, of what goes on in the classroom? Do we illustrate the complex 
connections between, on the one hand, what students often too easily characterize as 'theoretical' or 'textbook' and what they also too easily assume as 'practical' or 'real?' Do we support a renewed understanding of the ways in which knowledge and action are connected in any field of human endeavour?

This opening set of questions is meant to lay the groundwork for examples of teaching that attempt to link ideas and identity or, in other words, substance and skills. In any learning adventure, we expect to find students who are curious, open-minded, and perhaps somewhat dubious about their own aptitude for a new project. In a foundational first-year course in a legal education program, students expect to learn 'rules' related to real problems in society. They hope to develop skills that will be 'useful' to their later careers as lawyers. But they probably also assume that what gets talked about in their class sessions will have limited relevance to what they will actually do in their lives. Some may expect what they think will be 'professional training', and thus show little initial patience with what they think are 'academic' discussions. Others may not have any clear idea of career ambition, and they may feel at home with 'theoretical' knowledge rather than venturing into the daunting arena of 'lawyering.'

In "A Talk to Entering Students," a professor introduces the study of law in this way: "One never knows all the law; one never feels wholly confident about any step taken in the law. [I] $\mathrm{n}$ an uncertain and indeterminate world...the task...is to survive and flourish in it" (White, 1985 , p. 58). In any introductory course, teachers and students balance the objectives of knowledge and capacitybuilding. They work with content or substance, while at the same time figuring out who they are with respect to those ideas, and how to sharpen the skills that encourage flourishing.

\section{Canada's Residential School Legacy: An Example of 'Real Life' Pedagogy}

But all that is someday and far away. Today he has returned home and he is a stranger in his own land. He doesn't have any parents or grandparents and he doesn't understand his language. For nine years he wished he was out of that hellhole. He finally got his wish. But today, for some strange reason, he wishes he were back. He is confused by these feelings, but he doesn't dwell on it. He has to relearn his language and the ways of his People. His survival depends on it - literally. (Alexie, 2002, p. 16)

The choice of introducing students to the legacy of Canada's residential schools is aimed at developing both critical understanding of ideas and capacity for identitybased roles and responsibilities. As mentioned in the Introduction, the context is that of a foundational firstyear law course devoted to the governance of human interaction or interpersonal accountability. While any current issue of concern, with aspects of harmful behaviour and complex injury, might trigger student interest, residential schools carry a special resonance. As part of the history of Canada, the residential school system in place for roughly 100 years across the country affected not only the thousands of Aboriginal children enrolled in them, but also their families and communities. Immediately, students are reminded that harm can reach beyond the individual, and that entire societies can create policies and practices the impact of which requires complex listening and cooperative problem-solving on the part of all participants.

Stories in the words of survivors themselves impress upon the students the effects of separation, isolation, disconnection, and fear. The severe actions taken to punish transgressions, the mechanisms created to enforce authority, the failure to respect education and health standards, the patterns of physical and sexual abuse, and the loss of family ties and cultural confidence: all are captured in these accounts.

Considerable scholarship exists related to teaching aboriginal or indigenous perspectives, knowledge, and realities - much of it focused on teaching in primary and secondary schools (Czyzewski, 2011; Harrison \& Greenfield, 2011; Strong-Wilson, 2006). Bringing the residential school story to first year law students, however, is a unique project. My aim is not simply to inform students (who may well have a fairly sophisticated appreciation of many aspects of the residential school experience), nor primarily to evoke and deepen empathetic response. Rather, I mean to show students how narratives convey needs, needs provoke responses, and responses require imagination and action (Van Praagh, 1992). Students should feel like a burden has been placed on their 
shoulders as they open their minds to the study of law, that their reaction to human stories requires a particular kind of engagement.

How do we move beyond the stories, while holding on to their powerful resonance? In much the same way, these students, once lawyers, will need to listen, investigate, and translate the experiences and narratives to which they are asked to respond. In the words of Rita Joe (2009): '[G]ently I offer my hand and ask, / Let me find my talk, / So I can teach you about me..." (p. 129). The legal education upon which these students are embarking is all about listening to the 'talk' of others and learning what speakers have to say. However, it is also about thinking innovatively and rewriting roles.

The law students start with the range of human needs triggered by the residential school experience: from memory to therapy, from accountability to compensation, from community-building to formal acknowledgement. They are then asked to assess, based on those needs, the contours and characteristics of a range of regimes or systematic response mechanisms found in society. Those responses include education and formal apology, public inquiry and criminal justice, counseling and civil liability. The law students discover that their collective engagement in this range of processes allows them to better appreciate the strengths and weaknesses of each type of response, and the ways in which their co-existence may be the best way to move forward. Throughout the class exercise, students are asked to imagine themselves as group representatives, scrutinizing each response from the perspective of the communities dealing with past and ongoing harm.

This introductory session, grounded in the stories and projects associated with residential schools, prepares students for a focused course-long inquiry into civil liability, aware from the start that this is only one way in which individuals and groups search for reparation for past harm. As the course proceeds, the students are brought back to the starting example in order to reimagine rules through innovative analysis. For example, when they study the ways in which injury is defined and recognized by civil liability law, they realize that physical harm is 'easy', while emotional loss is 'difficult' and cultural loss perhaps 'impossible'. Here they develop their capacity to advocate for change, to push boundaries, to imagine different directions for law. They also learn to accept the limits of particular forms of law, and to look beyond state institutions for practices and policies that strengthen communities and that provide possibilities for intercommunity collaboration. These are lessons that gain in significance as the course moves from issue to issue, and as the students are invited to incorporate critical commentary into their in-class exercises and their more formal exams and written assignments.

As they come to appreciate how law can fail to 'hear' certain stories, the students are invited to place their knowledge and skills in perspective. They learn to search for new forms of investigation and participation: in other words, they prepare for the roles of negotiator, advisor, and leader that they may indeed take on in the future. They have learned much more than a 'real life' instance in Canadian history and contemporary reality that demands the substantive attention of lawyers in many capacities; instead they have learned through 'real life' pedagogy that the roles and responsibilities refined as law students in the classroom are precisely those exercised after graduation, no matter the career paths taken.

Focusing on pedagogy attuned to capacity building and reinforcement should not be confused with defining the study of law as instrumentalist, fixated on the society-changing functions and potential of legal rules and procedures. Education in law, as in other areas, is fundamentally about ideas and the enrichment of the students' minds and lives, but the approach taken to that study need not be disengaged from what it means to 'do' law in all its forms and sites and sizes. Feelings, responsible listening, sensitive analysis, and creative action are intertwined, and pedagogical approaches that underscore that mix turn meaningful experience in the classroom into real life, and vice versa, rather than imagining them as separate entities (Kahn, 1999; Macdonald, 2002; Minow, 1988, 1998).

\section{Conclusion: Reflection and Action}

My example of incorporating awareness of Canada's residential school legacy into the first-year law curriculum illustrates the potential for enriching that substantive choice with equally significant pedagogical choices that challenge the imagined line between real life and the classroom. So too, we might imagine focusing on responses in law and society to bullying in the schoolyard or on the internet; or, in another context, we might discuss and question the parameters of free speech on campus. These all are rich cross-disciplinary sites for 
investigating the features of high quality, responsive, flexible, and innovative teaching and learning. While they embody current issues of concern, they also invite imaginative forms of investigation and collaboration. In the legal education context, they prepare students for the overlapping roles of representation, negotiation, advocacy, policy drafting and leadership.

As I suggested in the Introduction, the lessons from this example stretch across the boundaries that often separate academic disciplines and programs of education. That is, instructors across multiple fields of inquiry are implicitly invited to search for relevant ways to intertwine substance and form so as to integrate real life and classroom learning. Learning about something is often tightly linked to actually doing it, and effective exercises that bring real life to the classroom illustrate that fruitful and even crucial linkage. While this discussion does not aim to impose parameters on similar exercises in other kinds of courses, it does illustrate general guidelines for combining content and pedagogical method in ways that foster strong knowledge and understanding together with developing abilities and responsibilities.

Grappling with the flexibility and limits of established principles in light of contemporary challenges is key not only to dynamic and meaningful education in the classroom, but to the actions undertaken by students after they complete their formal learning. When professors lead classroom exercises that examine the objectives and modalities of societal responses to human needs, they teach students how to assess, and participate in, a spectrum of governing mechanisms. When they invite students to imagine the application of old rules to new contexts, they illustrate the obligation to respond creatively to problems. When they work within the contours of meaningful policy design, they show students how to combine responsible listening with imaginative construction. Classroom and 'real life' merge through issues and pedagogical approaches that combine deep reflection with active participation.

\section{References}

Alexie, R.A. (2002). Porcupines and china dolls. Toronto: Stoddart.

Czyzewski, K. (2011). The truth and reconciliation commission of Canada: Insights into the goal of transformative education. International Indigenous Policy Journal, 2(3).

Harrison, N. \& Greenfield, M. (2011). Relationship to place: Positioning Aboriginal knowledge and perspectives in classroom pedagogies. Critical Studies in Education, 52(1).

Joe, R. (2009). I lost my talk. In P. Monture \& P.D. McGuire (Eds.), First voices: An Aboriginal women's reader (Vol. 10, pp. 129). Toronto: Inanna.

Kahn, P.W. (1999). The cultural study of law: Reconstructing legal scholarship. Chicago: University of Chicago Press.

Macdonald, R.A. (2002). Lessons of everyday law. Montreal: McGill-Queens University Press.

Minow, M. (1988). Feminist reason: Getting it and losing it. Journal of Legal Education, 38.

Minow, M. (1998). Keeping students awake: Feminist theory and legal education. Maine Law Review, 50.

Strong-Wilson, T. (2006). Bringing memory foreward: A method for engaging teachers in reflective practice on narrative and memory. Reflective Practice: International and Multidisciplinary Perspectives, 7(1).

Van Praagh, S. (1992). Stories in law school: An essay on language, participation and the power of legal education. Columbia Journal of Gender and Law, 2.

White, J.B. (1985). The study of law as an intellectual activity: A talk to entering students. In Heracles' bow: Essays on the rhetoric and poetics of the law (pp. 49-59). Madison, WI: University of Wisconsin Press.

\section{Acknowledgements}

Thanks go to McGill law student Miriam Clouthier for her research assistance, made possible by the support of 
the Social Sciences and Humanities Research Council of Canada for a team project on pedagogy and governance in legal education.

\section{Biography}

Shauna Van Praagh B.Sc., LL.B. (Toronto), LL.M., J.S.D. (Columbia) has been a professor of Law at McGill University since 1994, and is a member of McGill Institute of Comparative Law and Centre for Human Rights and Legal Pluralism. Her research and teaching interests lie in the areas of children and law, legal education, the law of obligations, legal traditions and social diversity. 